JURNAL ILMIAH KOMPUTERISASI AKUNTANSI, Vol. 14, No. 2, Desember 2021,pp. 240 - 246

p-ISSN : 1979-116X (print)

e-ISSN : 2614-8870 (online)

http://journal.stekom.ac.id/index.php/kompak

\title{
The Effectiveness Of Motor Vehicle Tax Collection On Increasing West Java Regional Original Income
}

\author{
Asri Ayu Lestari1, Okkeu Fhenica Wini Sari2, Karyadi3, Wahyu Trimastuti4 \\ 1Politeknik Piksi Ganesha \\ Jl. Gatot Subroto No.301, Bandung (022) 87340086, e-mail: aslestari@piksi.ac.id \\ 2 Politeknik Piksi Ganesha \\ Jl. Gatot Subroto No.301, Bandung (022) 87340086, e-mail: ofwinisari@piksi.ac.id \\ 3 Politeknik Piksi Ganesha \\ Jl. Gatot Subroto No.301, Bandung (022) 87340086, e-mail: karyadi1605@piksi.ac.id \\ 4 Politeknik Piksi Ganesha \\ Jl. Gatot Subroto No.301, Bandung (022) 87340086, e-mail: trimastuti@gmail.com
}

\section{ARTICLE INFO}

Article history:

Received 30 September 2021

Received in revised form 2 November 2021

Accepted 10 November 2021

Available online 1 Desember 2021

\begin{abstract}
ABSTRAK
Pelaksanaan otonomi perpajakan oleh pemerintah pusat dan daerah secara terpisah memberikan keleluasaan untuk lebih mandiri dalam pengaturan perpajakan guna meningkatkan pendapatan daerahnya masing-masing. Penelitian ini bertujuan untuk mengetahui apakah penerapan pemungutan pajak kendaraan bermotor yang dilaksanakan oleh Pemerintah Provinsi Jawa Barat efektif dalam meningkatkan Pendapatan Asli Daerah (PAD) di Jawa Barat. Metodologi yang digunakan dalam penelitian ini adalah kualitatif. Analisis data yang digunakan adalah analisis dengan cara menghitung efiktivitas pemungutan pajak. Hasil analisis data menunjukkan bahwa efisiensi pemungutan pajak kendaraan bermotor berdampak pada peningkatan pendapatan asli daerah di Jawa Barat.
\end{abstract}

Kata kunci : Efektivitas, pajak kendaraan bermotor, pendapatan asli daerah

\section{ABSTRACT}

The implementation of tax autonomy by the central and regional governments separately provides the flexibility to be more independent in tax arrangements in order to increase the income of each region. The objective of this research is to determine whether the West Java provincial government's application of vehicle tax collection is effective in increasing Regional Original Income (ROI) in West Java. The methodology used in this research is qualitative. Analysis of the data used is analysis by calculating the effectiveness of tax collection. The results of data analysis show that the efficiency of vehicle tax collection has an impact on increasing local revenue in West Java.

Keywords: Effectiveness, vehicle tax, local revenue

Received Se 30, 2021; Revised Nov 2, 2021; Accepted Nov 10, 2021 


\section{Introduction}

The State of Indonesia is a legal state based on Pancasila and the 1945 Constitution in protecting the rights and obligations of its citizens. Therefore, taxation is an expression of national obligations to its citizens and a means of participation in national financing and national development. Indonesia relies heavily on taxation as the largest source of national income to support government affairs and provide funds for national expenditure and development financing needs. On the other hand, taxation is also very important to regulate economic growth through taxation policies.

To realize equitable development for all people, the state grants autonomy to the central and local governments to collect taxes separately, in accordance with the provisions of Law Number 33 of (2004). The granting of this autonomy should make the central and regional governments more independent in managing their finances(Dore 2003). Tax collection is divided into two parts, namely central taxes and local taxes. Central taxes are managed and collected by the central government, namely The General Tax Directorate, which consists of the Income Tax $(\mathrm{PPh})$, the Value Added Tax (PPN), the Value Added Tax of Goods of Luxury (PPnBM), Stamp Tax and Property and Construction Tax.

Meanwhile, regional taxes administered by local governments are distributed at the provincial level, including vehicle taxes, vehicle transfer fees, vehicle fuel taxes, surface water taxes, and cigarette taxes. And at the government / city level, the tax consists of hotel tax, restaurant tax, entertainment tax, advertising tax, public lighting tax, mineral and non-metallic stone tax, parking tax, groundwater tax, tax. wallet bird's nest, land acquisition fees and taxes. or taxes on buildings and land and construction for rural and urban areas.

All autonomous countries, in this case the states or districts/cities of Indonesia, have great natural and economic resource potential. Therefore, when used properly with proper cash management, it can make a significant contribution to regional income, which benefits regional financial independence (Hasannudin and Wokas 2014).

Researchers believe that West Java has good tax potential, including provincial tax levies on motorized vehicles, because as a link between regions, transportation is very important for the mobility of various economic activities. Along with the growth rate of road transportation which continues to increase, land transportation also contributes to the improvement of the economy of West Java through tax contributions. According to the Central Statistics Agency in the Transportation Statistics Book of West Java Province (2019), the number of motorized vehicles increased significantly in five years, namely $7.37 \%$ per year from 2015 to 2019.

Based on the background that has been described, the researchers want to conduct research on the effectiveness of motor vehicle tax collection on increasing local revenue in West Java. The results of this research are intended to determine to what extent the effectiveness of vehicle tax collection affects the increase in local revenue of the West Java provincial government.

\section{Literature Review}

\subsection{Tax}

According to Mardiasmo (2016:3) Taxes are contributions of individuals to the state, which flow to the state treasury on the basis of laws and the implementation of which can be enforced without remuneration. The state uses these contributions to make public interest payments.

This element provides an understanding that people must pay taxes voluntarily and are fully aware that they are good citizens. Taxation is a continuously recoverable source of income that can be optimized and developed in accordance with the needs of the government and the circumstances of the community.

JURNAL ILMIAH KOMPUTERISASI AKUNTANSI Vol. 14, No. 2, Desember $2021: 240-246$ 


\subsection{Local Tax}

According to Madiasmo (2016:3)Regional taxes are mandatory contributions to regions that are owed by individuals or entities that are coercive in nature according to law without receiving direct compensation and are used for regional needs for the greatest prosperity of the people.

\subsection{Regional Original Income}

Regional Original Income (ROI) is one source of regional income that plays an important role in development. ROI according to the law number 33, article 1 (18) of 2004 concerns the fiscal balance of central and regional governments as the income obtained by regions collected on the basis of regional regulations in accordance with with legal provisions.

In accordance with Article 3 (1), The ROI is intended to enable local communities to fund the implementation of regional self-government as a sign of decentralization, depending on the region's potential. ROI is obtained from other legitimate ROI as a result of local taxes, local taxes, and local individual control (Sukmawati and Ishak 2019).

\subsection{Vehicle Tax}

Motor Vehicle Tax as defined in Article 1 paragraphs 12 and 13 of Law Number 28 of (2009) is a tax on ownership and/or control of motorized vehicles. Therefore, every person or entity that owns or controls a motorized vehicle is obliged to pay taxes to the regions for the progress and prosperity of the people in the local area.

\subsection{Motor Vehicle Tax Object}

The object of the motor vehicle tax in article 3 of Law No. 28 of (2009) is the ownership and / or control of motor vehicles. The definition of motorized vehicles includes motorized wheeled vehicles and their trailers that are used on all types of rural roads and motorized vehicles that operate on water with a gross volumeof GT 5 (five Gross Tonnage) to GT 7 (seven Gross Tonnage).

\subsection{Motor Vehicle Tax Subject}

The subject of the Motor Vehicle Tax as stated in Article 4 of Law Number 28 of (2009) is an individual or entity that owns and/or controls a motor vehicle. Mandatory motor vehicle tax is an individual or entity that owns a motorized vehicle. In the case of corporate taxpayers, tax obligations are represented by corporate management or a power of attorney.

\subsection{Basic Motor Vehicle Tax Imposition}

The tax base for motor vehicle tax under Article 5 of the Law of the Republic of Indonesia No. 28 of (2009) is obtained by multiplying 2 main elements, namely:

1. Value of motor vehicle sales; and

2. The weight, which represents the relative degree of damage and/or contamination of the roads due to the use of motorized vehicles.

\subsection{Effectiveness}

According to Mardiasmo (2009:132) Effectiveness is a measure of an organization's success or failure in achieving its goals. When an organization successfully achieves its objectives, it can be said that the organization has functioned effectively.

The Effectiveness Of Motor Vehicle Tax Collection On Increasing West Java Regional Original Income (Asri Ayu Lestari) 
3. Method

\subsection{Types Of Research}

The type of research used in this research is qualitative research according to Sugiyono (2017), that is research methods based on the philosophy of postpositivity that researchers use to investigate the condition of natural objects. (not experiments), collection (combination) using triangulation, data analysis is inductive or qualitative, and the results qualitative research results emphasize importance rather than generalizability.

\subsection{Data Source}

Sources of data used in this research are primary data and secondary data. Primary data comes from the Supreme Audit Agency (BPK) of West Java. Secondary data come from literature and journal studies and documents published by the West Java Provincial Government, in this case the West Java Regional Revenue Agency and the West Java Central Statistics Agency.

\subsection{Data Analysis Technique}

The data analysis techniques used are data reduction, data presentation and drawing conclusions. This method is related to Miles and Huberman's theory, and activities to perform data analysis in qualitative data analysis activities include data reduction (data reduction) and data visualization (data visualization), this includes an activity (Miles, Huberman, and Saldana 2013).

\subsection{Operational Definition And Measuremenr Of Variable}

\subsubsection{Effectiveness Analysis}

According to Mardiasmo (2009:134) Effectiveness is a measure of an organization's success or failure in achieving its goals. When an organization successfully achieves its objectives, it can be said that the organization has functioned effectively. Therefore, to determine the degree of tax effectiveness of motor vehicles by comparing the implementation of the collection of the motor vehicle tax with the aim of collecting the motor vehicle tax annually with the formula:

$$
\text { Effectiveness MVT }=\frac{\text { Realization of motor vehicle tax collection }}{\text { Target motor vehicle tax collection }} \times 100 \%
$$

If the result is equal to or greater than one percent (100\%), the motor vehicle tax will affect the local income. The following indicators are used to measure effectiveness:

Table 1

Classification of Effectiveness Criteria

\begin{tabular}{|c|c|}
\hline Percentage & Criteria \\
\hline$>100 \%$ & Very Effective \\
\hline $91-100 \%$ & Effective \\
\hline $81-90 \%$ & Effective enough \\
\hline $60-80 \%$ & Less Effective \\
\hline$<60 \%$ & Not Effective \\
\hline
\end{tabular}

Source: Ministry of Home Affairs, Ministry of Home Affairs No.690.900.327(Adelina 2012)

JURNAL ILMIAH KOMPUTERISASI AKUNTANSI Vol. 14, No. 2, Desember $2021: 240-246$ 


\subsubsection{Contribution Analysis}

According to Mahmudi (2010:145) this degree serves to determine the contribution level of regional companies in supporting regional income. This ratio can be calculated by comparing local revenue from motor vehicle tax collection with total local revenue. To find out the contribution of motor vehicle tax in local revenue, the formula used is as follows:

$$
\text { Contribution ROI }=\frac{\text { Realization of MVT }}{\text { Realization ROI }} \times 100 \%
$$

The following indicators to show the level of motor vehicle tax contribution to Regional Original Income are as follows:

Table 2

Contribution Criteria Classification

\begin{tabular}{|c|c|}
\hline Percentage & Criteria \\
\hline $0,00 \%-10 \%$ & Very Less \\
\hline $10,10 \%-20 \%$ & Less \\
\hline $20,10 \%-30 \%$ & Currently \\
\hline $30,10 \%-40 \%$ & Enough \\
\hline $40,10 \%-50 \%$ & Good \\
\hline Up to $50 \%$ & Very Good \\
\hline
\end{tabular}

Source: Ministry of Home Affairs, Ministry of Home Affairs No. 690.900.327(Velayati 2012)

\section{Discussion and Result Motor Vehicle Tax Collection Effectiveness}

Table 3

Target and realization of tax collection on motor vehicles of the West Java regional government in $2018-2020$

(in million rupiah)

\begin{tabular}{|c|c|r|r|c|}
\hline Year & Target ( Rp ) & Realization ( Rp ) & Percentage & Criteria \\
\hline 2018 & 7.180 .342 & 7.540 .802 & $105,02 \%$ & Very Effective \\
\hline 2019 & 8.034 .519 & 8.174 .357 & $101,74 \%$ & Very Effective \\
\hline 2020 & 10.147 .044 & 7.610 .389 & $75,00 \%$ & Less Effective \\
\hline \multicolumn{5}{|c|}{ Average } \\
\hline
\end{tabular}

Source: West Java Provincial Revenue Agency, (2021)

Provide a statement that what is expected, as stated in the "Introduction" chapter can ultimately result in "Results and Discussion" chapter, so there is compatibility. Moreover, it can also be added the prospect of the development of research results and application prospects of further studies into the next (based on discussion and result).

As shown in List 3 above, the average efficiency of the motor vehicle tax rate from 2018 to 2020 is $93.92 \%$. If the criteria or indicators are met, then the assessment is valid. This shows that the local government of West Java effectively manages the motor vehicle tax.

Table 4

Collection of Taxes on Motor Vehicles against local government revenue of West Java Province in $2018-2020$ 


\begin{tabular}{|c|c|c|c|c|}
\hline \multicolumn{5}{|c|}{ (in Million Rupiah) } \\
\hline Year & $\begin{array}{c}\text { Realization MVT ( } \\
\text { Rp ) }\end{array}$ & Realization ROI ( Rp ) & Percentage & Criteria \\
\hline 2018 & 7.540 .802 & 19.642 .915 & $38,39 \%$ & Enough \\
\hline 2019 & 8.174 .357 & 21.244 .267 & $38,48 \%$ & Enough \\
\hline 2020 & 7.610 .389 & 18.521 .882 & $41,09 \%$ & Good \\
\hline & Average & & $39,32 \%$ & Enough \\
\hline
\end{tabular}

Source: data processed 2021

As shown in Table 3 above, the average levy rate for vehicle revenues in the West Java area from 2018 to 2020 is $39,32 \%$, so it is quite good if assessed according to the standards or indicators above. This shows that the West Java regional government is very serious about monitoring, utilizing, and optimizing the source of motor vehicle tax revenue because its contribution to goverment is very good or satisfactory

\section{Motor Vehicle Tax Collection Effectiveness}

Picture 1 below is a graph that shows the effectiveness of tax collection on motor vehicles on local revenue

Picture 1

Motor Vehicle Tax Collection Effectiveness

West Java Province 2018-2020

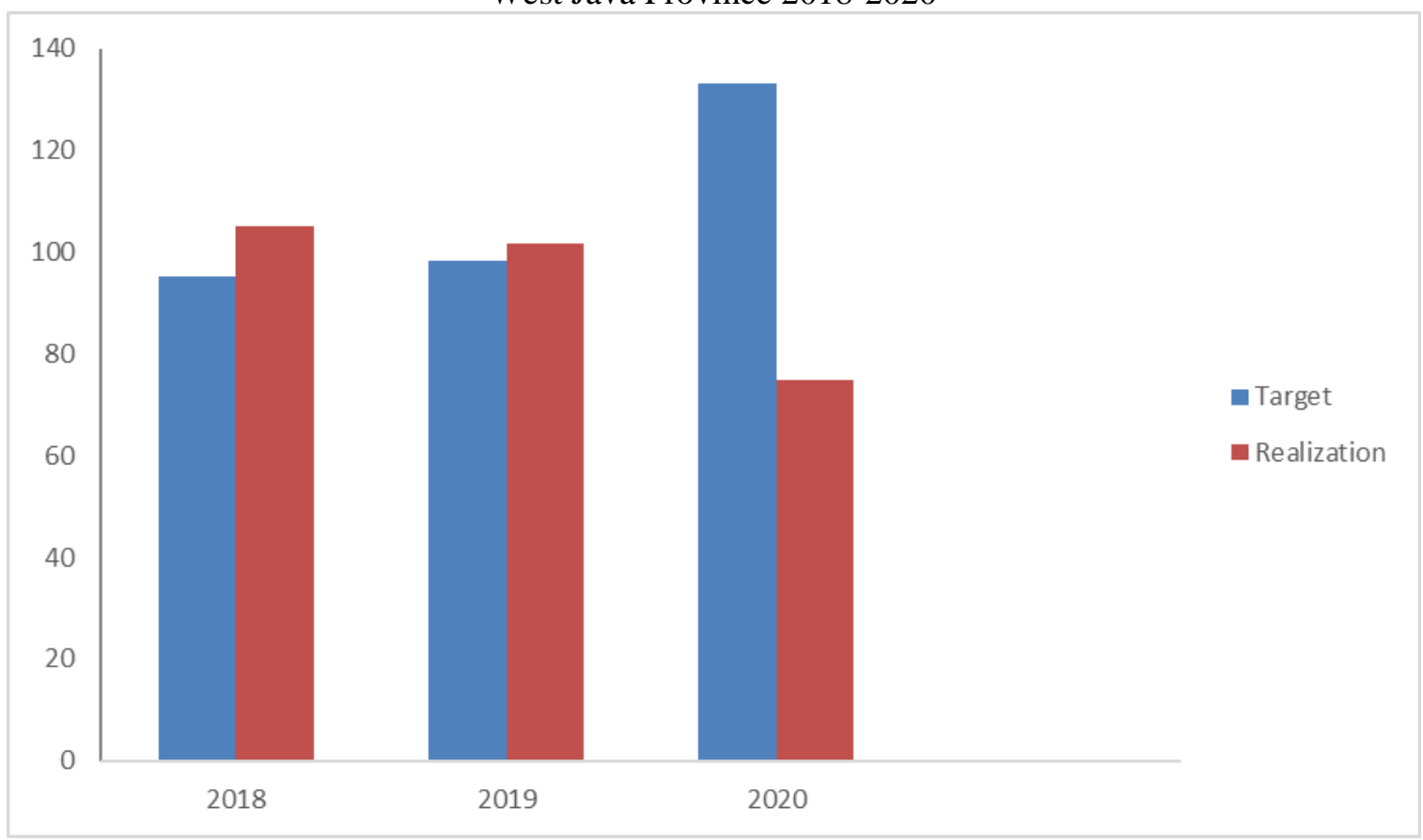

Source: Data processed, 2021

Picture 1 above shows the efficiency level of tax revenue on motor vehicles in 2018 was $105,02 \%$, indicating that motor vehicle tax revenues in 2018 were very effective. And in 2019 which was $101,74 \%$, the collection of taxes on motor vehicles in 2019 was very effective. Whereas in 2020 it was 75,00\%, this shows that tax collection on motor vehicles in 2020 is less effective. But the average drawdown in the 2018 to 2020 period is $93,92 \%$, and the results show that the collection of vehicle taxes during this period is effective. 
Motor Vehicle Tax Contribution to Regional Original Income

Picture 2 below is a graph showing the contribution of taxes on motor vehicles to local revenue

Picture 2

Tax Contribution on Motor Vehicles

Against local revenue

Regional Government of West Java Province 2018 - 2020

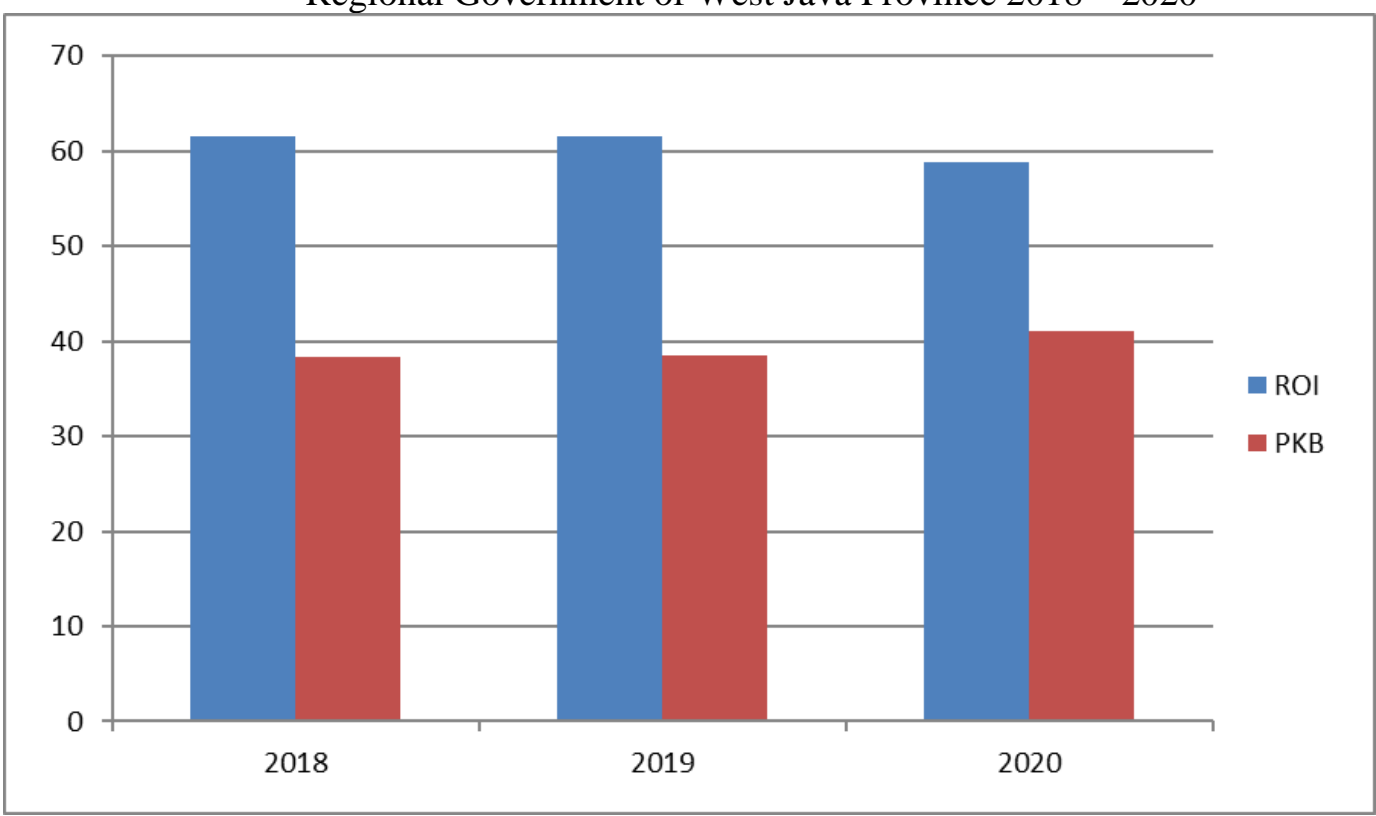

Source: Processed Data, 2021

Based on the above data processed by the researchers in Picture 2, it shows that the contribution of motor vehicle taxes in regional original income in 2018 is $38,39 \%$, while $61,61 \%$ is contributed by other types and local tax levies. This shows that the percentage of tax contributions on motor vehicles in local revenue in 2018 is quite good. In 2019 it was 38,48\%, while other types of local taxes and levies contributed $61,52 \%$. This shows that the percentage of tax contributions for motor vehicles in local revenue in 2019 is quite good. And in 2020 it is $41,09 \%$, while $58,91 \%$ is contributed by other types and regional taxes. This shows that the percentage of tax contributions for motor vehicles in regional income in 2020 is good.

So in the 2018-2020 period, the average is $39,32 \%$, and it can be concluded that the contribution of motor vehicle taxes to original income (ROI) is quite good. This explains that the West Java Provincial Government is quite serious in identifying, utilizing and optimizing the sources of tax revenue which are classified as motor vehicle taxes, and other factors that affect the increase in motor vehicle tax revenues.

\section{Conclusion}

The effectiveness of tax revenue on motor vehicles from 2018 to 2020 in West Java is classified as effective with an average value of $93,92 \%$. This shows that the West Java Regional ROI has the capacity and ability that is considered good or effective in collecting taxes on motorized vehicles on the original increase in the region.

The average tax contribution for motor vehicles in West Java's local revenue in the period 2018 - 2020 is categorized as quite good with a value of 39,32\%. This is because the West Java government is serious enough about identifying, exploring and optimizing motor vehicle tax

The Effectiveness Of Motor Vehicle Tax Collection On Increasing West Java Regional Original Income (Asri Ayu Lestari) 
objects. And the West Java provincial government in extracting regional levies has been quite good in increasing Regional Original Income.

The effectiveness of motor vehicle tax revenue has a significant influence on local revenues, if vehicle tax collection increases then ROI will also increase and vice versa, if motor vehicle tax collection decreases it will affect the decline in ROI in the West Java area.

\section{Suggestion}

The West Java Provincial Government can maintain, especially can increase taxpayer awareness, namely the community to pay taxes, including by increasing public service facilities to facilitate and facilitate the payment of motor vehicle taxes so that people will be motivated to participate in regional development.

The West Java Provincial Government always carries out systematic, regular and continuous monitoring and control so that the annual tax target and the realization of tax revenue can be successfully completed and local tax revenues increase.

The effectiveness of the motor vehicle tax contribution to the increase in regional originals in West Java during 2018-2020 continues to increase, it is better that this achievement be maintained for the coming years.

\section{Reference}

Adelina, Rima. 2012. “Analisis Efektifitas Dan Kontribusi Penerimaan Pajak Bumi Dan Bangunan (PBB) Terhadap Pendapatan Daerah DiKabupaten Gresik." Universitas Negeri Surabayar.

Badan Pusat Statistik. 2019. Statistik Provinsi Jawa Barat 2019. Bandung: BPS Provinsi Jawa Barat.

Dore, John. 2003. "The Governance of Increasing Mekong Regionalism."

Harjo, Dwikora. 2021. "Penggalian Potensi Perluasan Basis Pajak Daerah Provinsi Jawa Barat Dalam Menghadapi Pandemi Covid-19.” 8(1):1-9.

Hasannudin, and Heince R. N. Wokas. 2014. "Analisis Efektivitas Dan Kontribusi Pajak Kendaraan Bermotor Terhadap Penerimaan Pendapatan Asli Daerah Di Provinsi Maluku Utara."

Law Number 28 of 2009 on Local Taxes and Charges. 2009. "Undang-Undang No 28 Tahun 2009 Tentang Pajak Daerah Dan Retribusi Daerah."

Law Number 33 of 2004 on Financial Balance between Government and Local Government. 2004. Undang-Undang No 33 Tahun 2004 Tentang Perimbangan Keuangan Antara Pemerintah Dan Pemerintah Daerah.

Mahmudi. 2010. Analisis Laporan Keuangan Pemerintah Daerah. 2nd ed. Yogyakarta: Unit Penerbit dan Percetakan.

Mardiasmo. 2009. Akuntansi Sektor Publik. Yogyakarta: Andi.

Mardiasmo. 2016. Perpajakan Edisi Terbaru. Yogyakarta: Andi.

Miles, M. B., A. M. Huberman, and J. Saldana. 2013. Qualitative Data Analysis: A Methods Sourcebook. SAGE Publications.

Sugiyono. 2017. Metode Penelitian Pendidikan Pendekatan Kuantitatif, Kualitatif, Dan R\&D. Bandung: Alfabeta.

Sukmawati, Mia, and Jouzar Farouq Ishak. 2019. "Pengaruh Kontribusi Pajak Reklame Dan Pajak Restoran Terhadap Pendapatan Asli Daerah Di Kota Bandung." In Prosiding Industrial Research Workshop and National Seminar 10(1):1056-68.

Velayati, Mala Rizkika. 2012. "Penagihan Pajak Aktif Dengan Surat Teguran Dan Surat Paksa Sebagai Upaya Pencairan.” Universitas Brawijaya. 